Gut, 1978, 19, 735-742

\title{
Acid microclimate in coeliac and Crohn's disease: a model for folate malabsorption
}

\author{
M. L. LUCAS ${ }^{1}$, B. T. COOPER, F. H. LEI, I. T. JOHNSON, G. K. T. HOLMES, \\ J. A. BLAIR, AND W. T. COOKE \\ From the Department of Chemistry, University of Aston in Birmingham, and the Nutritional and Intestinal \\ Unit, The General Hospital, Birmingham
}

SUMMARY The surface $\mathrm{pH}$ of human proximal jejunum was measured in biopsy samples and found to be more acid than the phosphate buffer in which they were incubated. The in vitro jejunal surface $\mathrm{pH}$ was $5.93 \pm 0.05$ in control subjects and 6.19 \pm 0.09 in treated coeliac patients. A group of untreated coeliac patients with a surface $\mathrm{pH}$ of $6.56 \pm 0.14$ had a significantly less acid surface $\mathrm{pH}$ compared to controls, as did a group of Crohn's patients with a surface $\mathrm{pH}$ of $6 \cdot 21 \pm 0.04$. These two groups with a significantly raised surface $\mathrm{pH}$ were subdivisible into 'high' and 'low' groups. Surface $\mathrm{pH}$ was found to remain low in the treated coeliac and control groups but became more acid over the incubation period reaching almost normal values in the Crohn's group and the untreated coeliac group. There were significant inverse correlations between villous and microvillous height with initial surface $\mathrm{pH}$. The raised surface $\mathrm{pH}$ in untreated coeliac disease and Crohn's disease would alter the amount of a weak acid available for non-ionic diffusion. Therefore the present results may help to explain the folate malabsorption known to occur in untreated coeliac disease and the frequently seen low serum folate levels in Crohn's disease.

To account for deviations from the pH-partition hypothesis as applied to weak electrolyte transfer in the rat small intestine, Hogben and his colleagues (1959) proposed the existence of an acid microclimate on the surface of the gut. They argued that weak-electrolytes must be confronted with a region of acid pH lower than the measurable luminal $\mathrm{pH}$ if transfer were to be explained solely by non-ionic diffusion. Experiments in the rat with pH-microelectrodes (Lucas et al., 1975; Lucas and Blair, 1978) have demonstrated that such a region of acid $\mathrm{pH}$ exists having a value of at least $\mathrm{pH} 5.5$ when the bulk phase $\mathrm{pH}$ is $\mathbf{7 \cdot 4}$. Preliminary experiments have similarly demonstrated a low surface $\mathrm{pH}$ in man using biopsy samples from the proximal jejunum (Lucas et al., 1976; Cooper et al., 1977). Alterations in the $\mathrm{pH}$ of this microclimate have been suggested (Blair and Matty, 1974) as a cause of the folic acid malabsorption seen in coeliac disease (Cooke, 1968). The frequent occurrence of folate deficiency in Crohn's disease (Hoffbrand et al., 1968; Swan,

\footnotetext{
1Present address: Professor Rosenberg's Laboratory, Pritzker School of Medicine, University of Chicago, Chicago, Illinois, USA.

Received for publication 3 February 1977
}

1969; Eade et al., 1972) which is seen even when the jejunum is apparently uninvolved might also be associated with a deficient acid microclimate. For this reason $\mathrm{pH}$-electrodes were used to measure the $\mathrm{pH}$ at the surface of the jejunum in biopsy samples from normal subjects, patients with treated and untreated coeliac disease and in patients with Crohn's disease who have apparently normal proximal jejunum. The purpose of the present experiments was to measure the surface $\mathrm{pH}$ in these various groups and to correlate the jejunal surface pH with any alterations in jejunal morphology.

\section{Methods}

\section{ELECTRODE CONSTRUCTION AND} CHARACTERISTICS

The construction of $\mathrm{pH}$-microelectrodes based on the method of Portnoy (1967) has been described elsewhere in detail (Lucas and Blair, 1978). They consisted of $1 \mathrm{~mm}$ o.d. inert capillary glass having a pH-sensitive membrane across one end, forming a moderately convex surface, projecting approximately $35 \mu \mathrm{m}$ beyond the inert capillary glass. All electrodes gave a linear response over the pH 4-9 range of not less than $55 \mathrm{mV}$ per decade and 
had a resistance of $4 \times 10^{9} \Omega ; 95 \%$ of the maximal response was evident within 30 seconds.

\section{BIOPSY PROCEDURE}

Peroral jejunal biopsies were taken with a suction biopsy capsule (Roy-Choudhury et al., 1964) from control subjects and patients after an overnight fast. Samples were taken immediately for electrode experiments and measured by an experimenter unfamiliar with the criteria of gastroenterological diagnosis, which prevented unintentional bias. The delay between obtaining samples and immersion in buffer medium was less than one minute.

\section{CLINICAL NOTES}

\section{Normal subjects and coeliac patients}

Jejunal biopsies were taken on the basis of informed consent after an overnight fast and at the same time of day. The age and sex composition of the groups under consideration did not vary significantly. Control population surface $\mathrm{pH}$ did not alter with age of subject and therefore alterations in mean age and sex of the groups were not a significant source of error. Normal tissue was obtained from 19 subjects (10 men and nine women, mean age 36 years) who were either normal volunteers (range 13-75 years) (eight subjects) or patients who had absolutely normal jejunal histology and no demonstrable gastrointestinal disorder. Coeliac tissue was obtained from nine patients (five men and four women, mean age 42 years, range 14-68 years) before starting any treatment, including a gluten-free diet and from nine patients (five men and four women, mean age 46 years, range 27-73 years) who had been on a gluten-free diet for periods between one and 10 years.

\section{Crohn's patients}

Fifteen adult patients (seven men and eight women, mean age 37 years, range 21-70 years) with Crohn's disease which was diagnosed according to conventional criteria (Linder et al., 1963; Lockhart-Mummary and Morson, 1964) were selected randomly from patients on the basis of a radiologically normal jejunum.

The length of history of the disease varied from one year to 17 years. Of the patients, nine had involvement of the colon alone, and six had involvement of the terminal ileum either alone (three) or in addition to colonic involvement (three). No specific features of Crohn's disease were found in the jejunal biopsies except for raised plasma cell counts in the lamina propria, confirming that all patients had no apparent jejunal involvement.

Ten patients had had no bowel resection at any time and five patients had had one bowel resection each (one ileocaecal resection, one colectomy with ileorectal anastomosis, and three panproctocolectomy with ileostomy). Three patients were on steroids at the time of biopsy (one tablet ACTH $5 \mu$ daily, two tablets prednisolone $40 \mathrm{mg}$ and $20 \mathrm{mg}$ daily respectively, and two patients were taking salazopyrin). At the time of biopsy 11 patients had indices showing active disease (disease activity is indicated by haemoglobin less than $12.5 \mathrm{~g} / \mu$, serum albumen less than $40 \mathrm{~g} / \mathrm{l}$, and seromucoids greater than $1.5 \mathrm{~g} / \mathrm{l}$ ); four had normal indices.

ELECTRODE MEASUREMENT PROTOCOL

Jejunal samples of adequate size were pinned mucosal surface upwards in $10 \mathrm{ml}$ cork-buttomed flasks containing Krebs phosphate buffer gassed with $100 \% \mathrm{O}_{2}$ at $37^{\circ} \mathrm{C}$. Added to the buffer was $10 \mathrm{mM}$ glucose, a concentration known to cause maximal rates of jejunal acidification in the rat (Blair et al., 1975). Previously calibrated electrodes mounted on a Leitz micromanipulator were advanced on to the biopsy surface until the electrodes touched the villi and the whole preparation 'dimpled'.

The change in $\mathrm{pH}$ was recorded at one minute intervals over five minutes, during which time a steady $\mathrm{pH}$ reading was achieved. After this initial measurement the electrode was taken off the surface and the buffer $\mathrm{pH}$ rechecked. This procedure was repeated again after one hour, giving a surface $\mathrm{pH}$ reading, $\mathrm{pH}$, initially $\left(\mathrm{t}_{0}\right)$ and after 60 minutes $\left(t_{60}\right)$.

\section{LIGHT MICROSCOPY}

A piece of the jejunal biopsy was taken for routine histological examination. Sections $5 \mu$ thick were stained in haematoxylin and eosin, and villous height was measured using a standard technique (RoyChoudhury et al., 1966).

\section{ELECTRON MICROSCOPY}

Electron microscopic examination was possible on the jejunum of 11 subjects including two coeliac patients on a normal diet and one coeliac patient on a gluten-free diet, three normal subjects, and five patients with Crohn's disease. Freshly excised biopsy material was fixed by immersion in glutaraldehyde, post-fixed in osmium tetroxide, and embedded in Araldite resin. Representative sections were obtained from the villi, or from the luminal surface of material having a flattened mucosa, and examined on an AEI 801 electron microscope having a previously calibrated magnification scale.

STATISTICAL METHODS

Significance was tested using $t$ tests for paired and 
unpaired samples, as normal statistics are entirely appropriate for $\mathrm{pH}$ data (Lucas, 1977). As a check, the non-parametric Mann-Witney and Wilcoxon tests were applied but are not given here as no discrepancies were found using both these normal and non-normal statistics.

\section{Results}

\section{INITIAL SURFACE pH}

Surface $\mathrm{pH}$ was measured in all biopsy samples in the presence of $10 \mathrm{mM}$ glucose at the onset of incubation in a Krebs-phosphate buffer of $\mathrm{pH}$ $6.89 \pm 0.07$ (52). The mean surface $\mathrm{pH}$ in all groups (Fig. 1, Table 1a) was significantly more acid than the buffer $\mathrm{pH}(\mathrm{P}<0.001$ for all groups except untreated coeliac patients where the significance was $\mathbf{P}<0.02$ ). Significant differences in surface $\mathrm{pH}$ between the various groups became apparent on comparing them with the control surface $\mathrm{pH}$ of $5.93 \pm 0.05$ (19). The surface $\mathrm{pH}$ of $6.56 \pm 0.14$
(9) for the untreated coeliac group was significantly less acid $(P<0.005)$ than the control group, whereas, in contrast, the surface $\mathrm{pH}$ of $6.19 \pm 0.09$ (9) for the treated coeliac group was not. The surface $\mathrm{pH}$ for the Crohn's disease group of $6.21 \pm 0.04(15)$ was significantly $(P<0.01)$ less acid than the control group.

\section{CHANGES IN SURFACE PH WITH TIME}

The differences in surface $\mathrm{pH}$ between groups that were evident at the onset of incubation in the presence of glucose were not statistically significant at the end of the incubation period (Fig. 1, Table 1a). Although surface $\mathrm{pH}$ did not significantly change in the controls and in the tissues from treated coeliac patients, there was a significant move towards a more acidic surface $\mathrm{pH}$ in the previously less acidic Crohn's and untreated coeliac patients. This move towards more acid values was statistically significant in both groups.

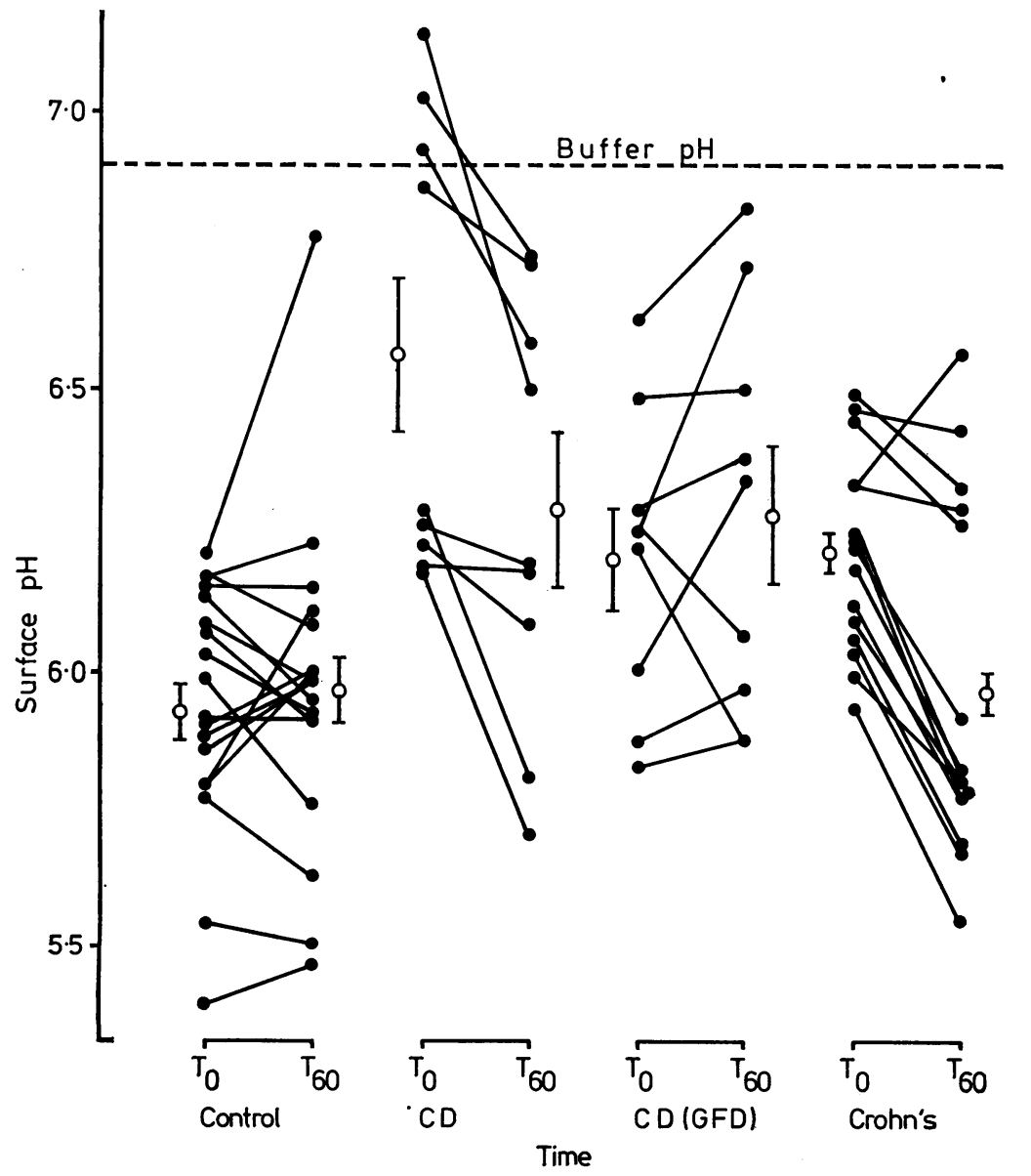

Fig. 1 Surface $\mathrm{pH}$ in the presence of $10 \mathrm{mM}$ glucose at the onset $\left(t_{0}\right)$ and end $\left(t_{60}\right)$ of incubation in control subjects, untreated coeliac patients $(C D)$, treated coeliac patients $(C D$ ( $G F D=$ gluten free diet $)$ ), and in Crohn's patients. 
Table 1a Analysis of Fig. 1

\begin{tabular}{|c|c|c|c|c|}
\hline $\begin{array}{l}\text { Buffer } p H \\
\text { Surface } p H\end{array}$ & $\begin{array}{l}t_{0} \\
6.89 \\
t_{0}\end{array}$ & (52) & $\begin{array}{l}t_{00} \\
6.85 \pm 0.03 \\
\text { Difference }\end{array}$ & Significance \\
\hline 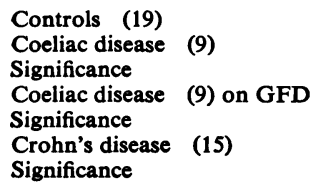 & $\begin{array}{l}5.93 \pm 0.05 \\
6.56 \pm 0.14 \\
P<0.005 \\
6.19 \pm 0.09 \\
\text { NS } \\
6.21 \pm 0.04 \\
P<0.01\end{array}$ & $\begin{array}{l}5.96 \pm 0.07 \\
6.28 \pm 0.13 \\
\text { NS } \\
6 \cdot 28 \pm 0.12 \\
\text { NS } \\
5.96 \pm 0.03 \\
\text { NS }\end{array}$ & $\begin{array}{r}-0.02 \pm 0.04 \\
0.29 \pm 0.07 \\
-0.09 \pm 0.08 \\
0.25 \pm 0.04\end{array}$ & $\begin{array}{l}\mathrm{NS} \\
\mathrm{P}<0.005 \\
\mathrm{P}<\mathrm{NS} \\
\mathrm{P}<0.001\end{array}$ \\
\hline
\end{tabular}

Surface pH of proximal jejunum incubated at $37^{\circ} \mathrm{C}$ in phosphate buffer containing $10 \mathrm{~mm}$ glucose. Results expressed as mean $\pm \mathrm{SEM}$. Number of observations in parentheses.

Table $1 \mathrm{~b}$ Effect of $10 \mathrm{~mm}$ glucose on surface $\mathrm{pH}$ of proximal jejunum

\begin{tabular}{|c|c|c|c|c|}
\hline a At onset of incubation & $10 \mathrm{mM}$ Glucose & No Glucose* & Difference & Significance \\
\hline $\begin{array}{l}\text { Controls (8) } \\
\text { CD (6) } \\
\text { CD on GFD (7) } \\
\text { Crohn's (11) } \\
\text { At end of incubation }\end{array}$ & $\begin{array}{l}5.84 \pm 0.10 \\
6 \cdot 49 \pm 0.21 \\
6 \cdot 21 \pm 0 \cdot 11 \\
6 \cdot 16 \pm 0.05\end{array}$ & $\begin{array}{l}6.28 \pm 0.07^{1} \\
6.79 \pm 0.22^{2} \\
6.42 \pm 0.11^{3} \\
6.48 \pm 0.05^{4}\end{array}$ & $\begin{array}{l}-0.46 \pm 0.09 \\
-0.31 \pm 0.10 \\
-0.21 \pm 0.07 \\
-0.28 \pm 0.07\end{array}$ & $\begin{array}{l}P<0.005 \\
P<0.05 \\
P<0.025 \\
P<0.02\end{array}$ \\
\hline $\begin{array}{l}\text { Controls (8) } \\
\text { CD (6) } \\
\text { CD on GFD (7) } \\
\text { Crohn's (11) }\end{array}$ & $\begin{array}{l}5.79 \pm 0.09 \\
6.21 \pm 0.13 \\
6.21 \pm 0.14 \\
5.85 \pm 0.07\end{array}$ & $\begin{array}{l}6.67 \pm 0.04^{1} \\
6.90 \pm 0.16^{2} \\
6.65 \pm 0.10^{2} \\
6.73 \pm 0.05^{4}\end{array}$ & $\begin{array}{l}-0.83 \pm 0.09 \\
-0.69 \pm 0.10 \\
-0.45 \pm 0.13 \\
-0.82 \pm 0.10\end{array}$ & $\begin{array}{l}P<0.001 \\
P<0.001 \\
P<0.02 \\
P<0.001\end{array}$ \\
\hline $\begin{array}{l}\text { *c Difference in surface } p \\
\Delta p H\left(t_{0}-t_{B_{0}}\right) \\
\text { 1. Controls (8) } \\
\text { 2. CD (6) } \\
\text { 3. CD on GFD (7) } \\
\text { 4. Crohn's (11) }\end{array}$ & I over incubation & $\begin{array}{l}\text { of glucose } \\
\text { Difference } \\
-0.39 \pm 0.07 \\
-0.11 \pm 0.07 \\
-0.24 \pm 0.10 \\
-0.26 \pm 0.06\end{array}$ & & $\begin{array}{l}P<0.001 \\
N S \\
P<0.05 \\
P<0.005\end{array}$ \\
\hline
\end{tabular}

*a: Presence and absence of glucose at $t_{0} . \mathrm{b}$ : Presence and absence of glucose at $t_{\mathrm{co}}$. c: Difference in surface pH over incubation period in absence of glucose. Details as for Table 1a.

\section{RESPONSE TO GLUCOSE}

Paired samples from the same biopsy enabled a comparison in the surface $\mathrm{pH}$ to be made in the presence and absence of glucose in all groups, at both the onset and end of incubation. The results in Table $1 \mathrm{~b}$ for surface $\mathrm{pH}$ in the presence of glucose represent therefore subsets from the data presented in Table 1a and Fig. 1. A significant difference could be demonstrated in all groups between surface $\mathrm{pH}$ in the presence and absence of glucose. In the absence of glucose the surface $\mathrm{pH}$ was higher in all cases, This difference became greater at the end of incubation. This was partly because the untreated coeliac group and the Crohn's group became more acid when incubated in the presence of glucose and partly because, in the absence of glucose, most groups tended to drift towards a neutral surface $\mathrm{pH}$.

This significant drift towards less acid values in the absence of glucose in most groups can be seen in Table 1b. Section (c) shows the mean differences in surface $\mathrm{pH}$ at the onset and end of incubation in the absence of glucose and was arrived at by subtracting the individual values that comprise the column in section (a) from those in section (b). There is a significant drift towards neutrality in the absence of glucose in every group except the untreated coeliac patients: this was because, in the absence of glucose the surface $\mathrm{pH}$ of this group is significantly raised even at the onset of incubation.

SURFACE PH IN ABSENCE OF GLUCOSE

The buffer $\mathrm{pH}$ at the onset and end of incubation is given in Table 1a and is representative for comparisons with all groups. At the beginning of incubation, with the exception of the untreated coeliac group there was a significantly more acid $(\mathrm{P}<0.01)$ surface $\mathrm{pH}$ in all groups. This difference between bulk and surface $\mathrm{pH}$ in the absence of glucose was also evident $(P<0.02)$ at the end of incubation but only in the control and treated coeliac group.

SUB-DIVISION INTO HIGH AND LOW GROUPS The individual results from both the Crohn's and untreated coeliac disease groups were subdivisible into two groups, 'high' and 'low' groups that were significantly distinct (Fig. 1). Both 'high' groups in untreated coeliac and Crohn's disease groups re- 


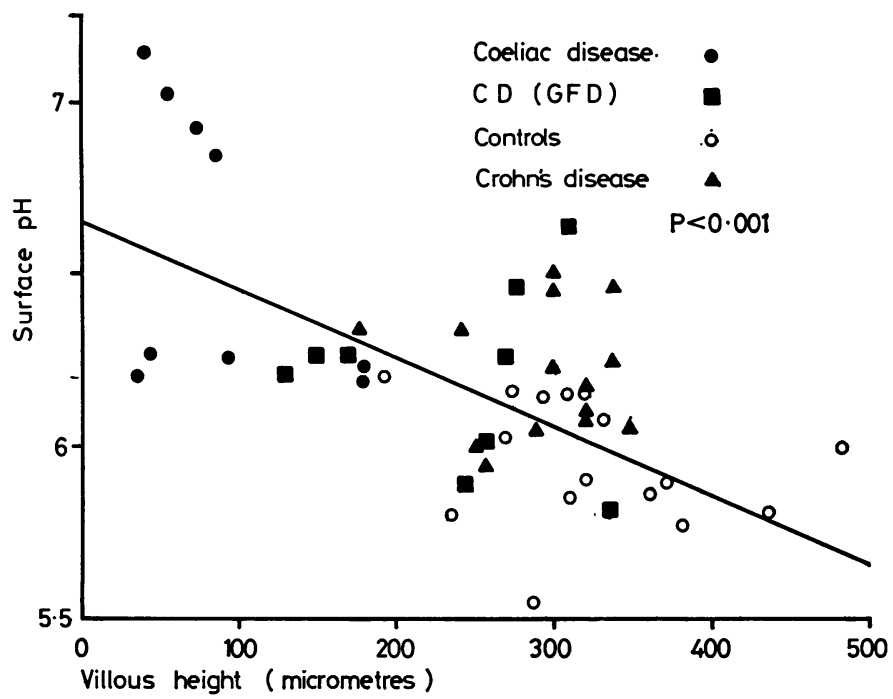

Fig. 2 Correlation between villous height and surface $\mathrm{pH}$ at the onset of incubation in the presence of $10 \mathrm{mM}$ glucose. Abbreviations as for Fig. 1 .

Table 2 Subdivision of surface pH results from Table la for untreated coeliac and Crohn's disease into 'high' and 'low' groups

\begin{tabular}{|c|c|c|c|c|c|}
\hline Crohn's disease & $t_{0}$ & $t_{80}$ & $\begin{array}{l}\text { Untreated coeliac } \\
\text { disease }\end{array}$ & $t_{0}$ & $t_{60}$ \\
\hline $\begin{array}{l}\text { 'High' (5) } \\
\text { Significance v. control } \\
\text { 'Low' (10) } \\
\text { Significance v. control } \\
\text { 'High' v. 'Low' }\end{array}$ & $\begin{array}{l}6.41 \pm 0.03 \\
P<0.001 \\
6.11 \pm 0.03 \\
P<0.05 \\
P<0.001\end{array}$ & $\begin{array}{l}6.38 \pm 0.05 \\
P<0.001 \\
5.76 \pm 0.03 \\
N S \\
P<0.001\end{array}$ & $\begin{array}{l}\text { 'High' (4) } \\
\text { 'Low' (5) }\end{array}$ & $\begin{array}{l}6.99 \pm 0.06 \\
P<0.001 \\
6.23 \pm 0.02 \\
P<0.001 \\
P<0.001\end{array}$ & $\begin{array}{l}6.63 \pm 0.05 \\
P<0.001 \\
5.97 \pm 0.12 \\
\text { NS } \\
P<0.001\end{array}$ \\
\hline
\end{tabular}

mained high over the incubation period; in contrast, both 'low' groups whose surface $\mathrm{pH}$ was still significantly higher than the control surface $\mathrm{pH}$ $(P<0.05)$ developed a final surface $\mathrm{pH}$ which was not significantly different from the controls. No such subdivision could be detected in the control or treated coeliac group (Table 2).

\section{MORPHOLOGICAL AND OTHER FINDINGS}

No significant correlations emerged between villous height and surface pH for the individual results within groups. When all results were considered there was a significant association (Fig. 2) between villous height and the surface $\mathrm{pH}$ at the onset of incubation in the presence of glucose; this association remained significant $(P<0.05)$ even when the four results from the 'high' group of untreated coeliac patients were discounted. From electron micrographs, microvillous height and glycocalyx depth was measured (Table 3). An inverse correlation (figure not shown) was found $(r=0.65$, $\mathrm{P}<0.05, \mathrm{n}=11$ ) between surface $\mathrm{pH}$ and microvillous height-that is, the shorter the microvilli, the less acidic the surface $\mathrm{pH}$. There was also a direct correlation $(r=0.64, \quad \mathrm{P}<0.05, \mathrm{n}=10)$ between fuzz depth and surface $\mathrm{pH}$ - that is, increasing fuzz depth was associated with a less acidic surface $\mathrm{pH}$.

No significant correlations could be found between serum folate levels and surface $\mathrm{pH}$ for the individual results within any group: a general trend was visible when surface $\mathrm{pH}$ was correlated with mean serum folate levels for the four groups in which mean surface $\mathrm{pH}$ is inversely related to serum folate.

\section{Discussion}

Using the most frequently available samples of human gut tissue, the present in vitro experiments demonstrate that, when biopsy samples are incubated in phosphate buffer, differences are apparent between the $\mathrm{pH}$ measured at the jejunal surface and the $\mathrm{pH}$ measured in the bulk phase of the incubation medium. As with all in vitro methods, the relevance to in vivo circumstances must be examined. Two major differences exist between the in vitro incubation system and conditions in vivo: the buffer composition, and the fact that, in the interdigestive or fasting state in vivo, glucose enters predominantly from the serosal side through the basolateral 
Table 3 Morphological data and serum folate levels

\begin{tabular}{|c|c|c|c|c|}
\hline & Villous height ( $\mu \mathrm{m})$ & Microvillous height $(\mu \mathrm{m})$ & Fuzz depth* $(\mu m)$ & Serum folates $(\mu \mathrm{g} / \mathrm{l})$ \\
\hline Controls & $329 \pm 15$ & $\begin{array}{l}1 \cdot 16(3) \\
(0 \cdot 93,1 \cdot 3,1 \cdot 25)\end{array}$ & $\begin{array}{l}0.07(2) \\
(0.08,0.06)\end{array}$ & $6 \cdot 50 \pm 1 \cdot 50(10)$ \\
\hline Coeliac disease (normal diet) & $87 \pm 19(9)$ & $\begin{array}{l}0.75(2) \\
(0.84,0.66)\end{array}$ & $\begin{array}{c}0 \cdot 11(2) \\
(0 \cdot 12,0.09)\end{array}$ & $2.03 \pm 0.44$ \\
\hline $\begin{array}{l}\text { Significance } \\
\text { Coeliac disease (gluten-free diet) } \\
\text { Significance } \\
\text { Crohn's disease } \\
\text { Significance }\end{array}$ & $\begin{array}{l}P<0.001 \\
237 \pm 24(8) \\
P<0.01 \\
292 \pm 12(14) \\
\text { NS }\end{array}$ & $\begin{array}{l}1 \cdot 25(1) \\
1.51 \pm 0.17(5)\end{array}$ & $\begin{array}{l}0.11 \text { (1) } \\
0.07 \pm 0.01\end{array}$ & $\begin{array}{l}P<0.02 \\
4.23 \pm 0.75(8) \\
\text { NS } \\
3.91 \pm 1.08(14) \\
\text { NS }\end{array}$ \\
\hline
\end{tabular}

*Rssults are given as either mean \pm SEM or as the mean with the individual results in parentheses under the mean.

enterocyte membranes.

Phosphate buffer was chosen to avoid the fluctuations in buffer $\mathrm{pH}$ seen in bicarbonate buffer in open systems, as it was important to stabilise the buffer $\mathrm{pH}$. However, surface $\mathrm{pH}$ is unaffected by choice of phosphate or bicarbonate buffer (Lucas and Blair, 1978) in the rat: similarly, preliminary studies with biopsy samples in a bicarbonate containing buffer also show an acid surface $\mathrm{pH}$ $(6 \cdot 10 \pm 0 \cdot 11$ (6)) similar to the results presented here. Although the biopsies were pinned out onto cork bases this was never sufficient to prevent serosal access of glucose: nevertheless in vitro the main route of glucose entry may be via the mucosally sited active pathway. The delay between obtaining fresh biopsy samples and their eventual immersion in buffer was minimal and indeed much less than most in vitro methods. Consequently, it is unlikely that the initial $\mathrm{pH}$ measurements were much affected by this change in the route of glucose access and it is difficult to envisage that freshly obtained biopsies had greatly differing initial intracellular glucose concentrations or that they could be depleted in the short time between biopsy and immersion in buffer.

In similar experiments in the rat (Lucas and Blair, 1978) an absence of glucose in the buffer caused a rise in the surface $\mathrm{pH}$, as did metabolic inhibitors, anoxia, and the removal of sodium ions. In biopsy samples, the omission of glucose from the buffer causes a rise in the surface $\mathrm{pH}$. Biopsies which were incubated for six hours or more, when it might be assumed that the tissue was undergoing autolysis, lost the ability to maintain the surface $\mathrm{pH}$ more acid than the buffer. These observations strongly suggest that the maintenance of an acid surface $\mathrm{pH}$ is dependent on the adequate in vitro functioning of the tissues. If an acid surface pH were to be caused by a moment of transient anoxia between biopsy and immersion, immersion in oxygenated buffer containing glucose should re-establish the originally neutral surface $\mathrm{pH}$, which was not the case. Also the absence of substrate would lead to a loss of cellular function over incubation and if this were the origin of the low surface $\mathrm{pH}$, the surface $\mathrm{pH}$ would be more acidic in the absence of glucose. Since the surface $\mathrm{pH}$ was always less acidic in the absence of glucose in all groups studied and, further, that in the absence of glucose most groups became neutral on incubation, it was felt that the ability to demonstrate a significantly lower surface $\mathrm{pH}$ in the presence of glucose in all groups, both at the onset and end of incubation, adequately demonstrated the viability of the biopsy samples in all the groups concerned.

The apparent existence of subgroups within the two abnormal groups could reflect a difference in the extent of pathological change affecting the mucosa. In untreated coeliac disease, these subgroups may relate to similar variability in folic acid absorption (Cox et al., 1958; Elsborg and Bastrup-Madsen, 1976). Within the subgroups in Crohn's patients, there was no correlation between surface $\mathrm{pH}$ and disease activity, site of macroscopic disease, length of history, treatment, or jejunal histology. Thus the variation in surface $\mathrm{pH}$ was not explained by other features of the disease.

A condition for the adequate maintenance of a low surface pH could be normal villous and microvillous architecture. Histological studies have shown an association between decreasing microvillous and villous height and a less acidic surface $\mathrm{pH}$. Removing the Crohn's group, which is not characterised by a reduction in villous height, makes the correlation between surface $\mathrm{pH}$ and villous height more significant. This may mean that there is a failure to produce hydrogen ions which is compounded by the absence of villi in untreated coeliac disease that prevents pooling of hydrogen ions between villi, leading to an even greater rise in the surface $\mathrm{pH}$. If the glycocalyx acts as a diffusion barrier to hydrogen ions (Blair and Matty, 1974), then thinning of the glycocalyx seen in untreated coeliac disease (Falchuk et al., 1974) could cause a rise in surface pH. However, the predicted relationship between surface pH and glycocalyx thickness was not evident in the small sample examined and, in fact, the 
reverse association was found. This may mean that qualitative rather than quantitative changes in the glycocalyx alter hydrogen ion diffusion.

Changes in surface pH in untreated coeliac disease and Crohn's disease over the incubation period in the presence of glucose are not simply related to a lower rate of glucose entry in vitro through the active pathway. A low rate of glucose entry, leading to a low rate of hydrogen ion production through metabolism of transported glucose, would only lower the surface $\mathrm{pH}$ to more acid values if the compartment in which surface $\mathrm{pH}$ is measured is closed off to the lumen-that is, if hydrogen ions were secreted into a closed system. The loss from this compartment, which is open to the lumen, depends on physical parameters only. Provided these do not change-for example, no change in the hydrogen ion diffusion coefficient or in the thickness of any retaining layer-a change in surface $\mathrm{pH}$ can only represent an increase in hydrogen ion production by the cells per se or achieved secondarily by increased glucose entry or metabolism. These surface $\mathrm{pH}$ changes point possibly to the absence in vitro of an inhibitory factor acting either on the system that produces hydrogen ion or in the input of glucose into that system in untreated coeliac and Crohn's disease.

A more acid $\mathrm{pH}$ on the jejunal surface would alter the concentrations of unionised forms of acids and bases immediately next to the enterocyte membrane such that the proportion of unionised form available for diffusion will differ completely from that in the bathing medium. Alterations in the surface $\mathrm{pH}$ would therefore affect the rate of transfer of weak electrolytes. As predicted by the $\mathrm{pH}$ partition hypothesis, alkalinising the jejunum in vivo decreases the transfer of folic acid (Benn et al., 1971; MacKenzie and Russell, 1976). The malabsorption of weak acids such as folic acid, as is frequently seen in untreated coeliac disease, is often explained in terms of the reduced surface area available for diffusion or by the reduced transfer of glucose, sodium ion, and fluid (Gerson et al., 1974). However, an altered $\mathrm{pH}$ microclimate at the gut wall would explain weak acid malabsorption equally as well but would further explain why in partial villous atrophy, more quinine $(\mathrm{pKa}=8.4)$ is absorbed than in healthy subjects (Mattila et al., 1973), despite a presumed reduction in both surface area and glucose transfer capacity. The raised surface $\mathrm{pH}$ values presented here would help to explain the low serum folate levels seen in untreated coeliac disease and their resumption to normal values in treated disease. The present data also indicate an altered surface $\mathrm{pH}$ in Crohn's disease and imply a malabsorptive component to the low serum folate levels frequently seen in this disease. The altered surface $\mathrm{pH}$ in Crohn's disease adds to a growing body of evidence (Goodman et al., 1976; Dunne et al., 1977) which points to abnormalities in apparently uninvolved small bowel in this disease.

The authors are grateful for support from the Wellcome Foundation (M.L.), the N.H.S. (B.T.C.), the British Council (F.H.L.), and the S.R.C. (I.T.J.).

\section{References}

Benn, A., Swan, C. H. J., Cooke, W. T., Blair, J. A., Matty, A. J., and Smith, M. E. (1971). Effect of intraluminal pH on the absorption of pteroylmonoglutamic acid. British Medical Journal, 1, 148-150.

Blair, J. A., Lucas, M. L., and Matty, A. J. (1975). Acidification in the rat proximal jejunum. Journal of Physiology, 245, 333-350.

Blair, J. A., and Matty, A. J. (1974). Acid microclimate in intestinal absorption. Clinics in Gastroenterology, 3, 183-198.

Cooke, W. T. (1968). Adult coeliac disease. In Progress in Gastroenterology, Vol. 1, pp. 299-338. Edited by G. B. J. Glass. Grune and Stratton: New York.

Cooper, B. T., Lucas, M. L., Lei, F. H., Blair, J. A., and Cooke, W. T. (1977). Abnormal jejunal surface pH in Crohn's disease-new evidence that Crohn's disease is a diffuse lesion of the gastrointestinal tract (Abstract). Gut, 18, 423.

Cox, E. V., Meynell, M. J., Cooke, W. T., and Gaddie, R. (1958). The folic acid excretion test in the steatorrhea syndrome. Gastroenterology, 35, 390-397.

Dunne, W. T., Allan, R. N., and Cooke, W. T. (1976). Enzymatic and quantitative histological evidence for Crohn's disease as a diffuse lesion of the gastrointestinal tract (Abstract). Gut, 17, 399.

Eade, M. N., Cooke, W. T., and Williams, J. A. (1972). Clinical and hematologic features of Crohn's disease. Surgery, Gynecology, and Obstetrics, 134, 643-646.

Elsborg, L., and Bastrup-Madsen, P. (1976). Folic acid absorption in various gastrointestinal disorders. Scandinavian Journal of Gastroenterology, 11, 333-335.

Gerson, C. D., Cohen, N., Brown, N., Lindenbaum, J., Hepner, G. W., and Janowitz, H. D. (1974). Folic acid and hexose absorption in sprue. American Journal of Digestive Diseases, 19, 911-919.

Goodman, M. J., Skinner, J. M., and Truelove, S. C. (1976). Abnormalities in the apparently normal bowel mucosa in Crohn's disease. Lancet, 1, 275-278.

Hoffbrand, A. V., Stewart, J. S., Booth, C. C., and Mollin, D. L. (1968). Folate deficiency in Crohn's disease: incidence, pathogenesis and treatment. British Medical Journal, 2, 71-75.

Hogben, C. A. M., Tocco, D. J., Brodie, B. B., and Schanker, L. S. (1959). On the mechanism of intestinal absorption of drugs. Journal of Pharmacology and Experimental Therapeutics, 125, 275-282.

Linder, A. E., Marshak, R. H., Wolf, B. S., and Janowitz, H. D. (1963). Granulomatous colitis-a clinical study. New England Journal of Medicine, 269, 379-385.

Lockhart-Mummery, H. E., and Morson, B. C. (1964). Crohn's disease of the large intestine. Gut, 5, 493-509.

Lucas, M. L. (1977). pH or hydrogen ion concentration in statistics? (Letter). Lancet, $2,826$.

Lucas, M. L., and Blair, J. A. (1978). The magnitude and distribution of the acid microclimate in proximal jejunum 
and its relation to luminal acidification. Proceedings of the Royal Society Series B, 200, 27-41.

Lucas, M. L., Blair, J. A., Cooper, B. T., and Cooke, W. T. (1976). Relationship of the acid microclimate in rat and human intestine to malabsorption. Biochemical Society Transactions, 4, 154-156.

Lucas, M. L., Schneider, W., Haberich, F. J., and Blair, J. A. (1975). Direct measurement by pH-microelectrode of the pH-microclimate in rat proximal jejunum. Proceedings of the Royal Society Series B, 192, 39-48.

MacKenzie, J. F., and Russell, R. I. (1976). The effect of pH on folic acid absorption in man. Clinical Science and Molecular Medicine, 51, 363-368.

Mattila, M. J., Jussila, J., and Takki, S. (1973). Drug absorption in patients with intestinal villous atrophy. Arznei-
mittel-Forschung, 23, 583-585.

Portnoy, H. D. (1967). The construction of glass electrodes. In Glass Electrodes for Hydrogen and other Cations, pp. 248-250. Edited by G. Eisenman. Arnold: London.

Roy-Choudhury, D. C., Cooke, W. T., Tan, D. T., Banwell, J. G., and Smits, B..J. (1966). Jejunal biopsy-criteria and significance. Scandinavian Journal of Gastroenterology, 1, 57-74.

Roy-Choudhury, D. C., Nicholson, G. I., and Cooke, W. T. (1964). Simple capsule for multiple intestinal biopsy specimens. Lancet, 2, 185-186.

Swan, C. H. J. (1969). The Haematological Complications of Regional Enteritis with Special Reference to Folate Deficiency. Thesis: University of Birmingham. 